\title{
Effect of the Growth Regulator Paclobutrazol and Fertilization on Defensive Chemistry and Herbivore Resistance of Austrian Pine (Pinus nigra) and Paper Birch (Betula papyrifera)
}

\author{
Rodrigo A. Chorbadjian, Pierluigi Bonello, and Daniel A. Herms
}

\begin{abstract}
The Growth/Differentiation Balance Hypothesis predicts that environmental factors that limit growth of plants more than their rate of photosynthesis should increase secondary metabolism and resistance to insects. Soil drench application of the plant growth regulator paclobutrazol slowed the growth of paper birch (Betula papyrifera) and Austrian pine (Pinus nigra) with no effect on photosynthesis. In response, foliar concentrations of condensed tannins (but not total phenolics) in birch increased as predicted, which increased birch resistance to gypsy moth (Lymantria dispar) and whitemarked tussock moth (Orgyia leucostigma), but only during the second season after treatment. In both years, there was a negative correlation between foliar concentrations of total phenolic and condensed tannins and growth of paper birch, which is consistent with the predicted trade-off between growth and defense. Conversely, in Austrian pine, paclobutrazol and fertilization did not have an effect on foliar concentration of tannins, phenolics, and terpenes, nor did the treatments have any effect on resistance to European pine sawfly (Neodiprion sertifer). Hence, the effects of paclobutrazol on tree growth, defensive chemistry, and insect resistance were species-specific and time sensitive.

Key Words. Allocation Trade-offs; Growth/Differentiation Balance Hypothesis; Growth Regulator; Insect Resistance; Plant Defense Theory.
\end{abstract}

Secondary metabolites are important defenses of plants to insects and pathogens, and their concentration can be mediated by resource-based allocation trade-offs between growth and other functions (Herms and Mattson 1992; Herms and Mattson 1997; Herms 2002). The Growth/Differentiation Balance Hypothesis predicts that environmental factors that reduce plant growth with little effect on photosynthesis should increase the availability of resources allocated to the production of secondary metabolites, thereby increasing resistance to insects and other herbivores (Herms and Mattson 1992; Glynn et al. 2007).

The plant growth regulator paclobutrazol reduces plant growth, which may reduce the need for mechanical pruning of shade trees in urban settings and utility rights-of-way (Mann et al. 1995), although tree species can vary in their sensitivity to this growth regulator (e.g., Bai et al. 2004). Paclobutrazol decreases plant growth by inhibiting gibberellin biosynthesis (Rademacher 2000) without diminishing photosynthetic rate (Wieland and Wample 1985; Archbold and Houtz 1988; Vu and Yelenosky 1988; Yim et al. 1997). It reduces plant growth without directly interfering with secondary metabolite biosynthetic pathways, as it inhibits gibberellin synthesis downstream in the chain of reactions leading to the production of secondary metabolites, i.e., the biosynthesis of tannins, phenolic compounds, and terpenoids (Rademacher 2000). Hence, in the context of the Growth/Differentiation Balance Hypothesis, it can be hypothesized that paclobutrazol will increase availability of photosynthate for allocation to secondary metabolism and thus increase plant resistance to herbivores. Indeed, some studies have found that paclobutrazol can enhance the resistance of plants to insect pests (Raese and Burts 1983; Campbell et al. 1989; Coffelt et al. 1993), pathogens (Blaedow et al. 2006; DeStefano et al. 2007; Collins and Rawnsley 2008; but see Hartman et al. 2009) and water stress (Marshall et al. 2000; Percival and AlBalushi 2007).

Conversely, nitrogen fertilization generally increases growth with less effect on photosynthesis, which has been associated with reduced insect resistance (Herms 2002). Fertilization increases growth rate because trees are stimulated to allocate a greater proportion of their carbon to production of new leaf area. However, root growth is proportionally decreased, as are concentrations of storage and defensive compounds (e.g., phenolics and other secondary metabolites) (Herms and Mattson 1997; Herms 2002; Glynn et al. 2007). Fast-growing plants typically have lower mass per leaf area (specific leaf mass), which is generally associated with lower levels of plant defensive chemicals and increased leaf nitrogen $(\mathrm{N})$ content, both factors being beneficial to insect growth (Herms and Mattson 1992; Herms and Mattson 1997).

The objective of this study was to quantify the effects of paclobutrazol and fertilization, separately and in combination, on growth, photosynthesis, phytochemistry, and leaf morphology of paper birch (Betula papyrifera) and Austrian pine (Pinus nigra), as well as their resistance to key defoliating insect pests. Specifically, the researchers quantified growth and survival of gypsy moth (Lymantria dispar), forest tent caterpillar (Malacosoma disstria), and white-marked tussock moth (Orgyia leucostigma) larvae on paper birch, and European pine sawfly (Neodiprion sertifer) larvae on Austrian pine. 


\section{MATERIALS AND METHODS}

\section{Experimental Design and Treatments}

The study was conducted in 48 individual, physically isolated soil cells (phytotrons) located at the Ohio Agricultural Research and Development Center in Wooster, Ohio, U.S. Each phytotron was constructed by slicing a narrow trench one meter deep, around plots $4 \mathrm{~m}^{2}$ in area. The perimeter of each phytotron was lined with 30 mil PVC landfill liner extending one meter vertically into and $20 \mathrm{~cm}$ above the ground, which was heat welded at the overlap to completely enclose the plot. The liner isolated the soil environment without affecting drainage, allowing for establishment of replicated, randomized soil environments. The native soil is a Canfield silt loam (29\% sand, $42 \%$ silt, $29 \%$ clay). A single paper birch (avg. height: $1.1 \pm 0.07 \mathrm{~m}$ ) was planted in the corner of each plot on September 20, 2000, and a single Austrian pine (avg. height: $1.0 \pm 0.12 \mathrm{~m}$ ) was added to the opposing corner of each plot on September 12, 2002. Weeds were controlled with pre-emergence herbicides (isoxaben and oryzalin or prodiamine) in combination with manual cultivation and spot treatment with glyphosate.

The experiment was designed as a randomized complete block, with four treatments: 1) untreated control, 2) paclobutrazol soil drench, 3) fertilizer, and 4) paclobutrazol + fertilizer. There were 12 replicate trees per treatment, with each treatment combination replicated four times in each of three blocks. Paclobutrazol was applied via soil drench on September 19, 2002, to both paper birch and Austrian pine using the commercial product Cambistat 2SC (22.3\% paclobutrazol) at the labeled rate of $17 \mathrm{ml}$ per $2.54 \mathrm{~cm}$ trunk diameter. Trunk diameter was measured at $50 \mathrm{~cm}$ from ground level. The fertilization treatment consisted of 3:1:1 N:P:K with $60 \%$ of $\mathrm{N}$ in slow release form (urea formaldehyde) and $40 \%$ in fast release form (ammonium and nitrate) applied to the soil surface at a rate of $200 \mathrm{Kg} \mathrm{N} / \mathrm{ha} / \mathrm{yr}$, with half the annual rate applied just after bud break in the spring, and the other half prior to leaf drop in late summer or early autumn. The fertilization treatment represents an intermediate rate based on standard recommendations for woody plants (ANSI 2004). Trees were fertilized in May and September each year through 2005, with fertilization of paper birch and Austrian pine commencing in May 2001 and September 2002, respectively.

Treatment effects on tree physiology, secondary metabolism, and insect resistance were measured in 2003 and 2004 for paper birch, and from 2003 to 2005 for Austrian pine. Pine trees were maintained for an additional year to test for any lagging effects of treatments on resistance to European pine sawfly, which feeds on needles that are one year old or older.

\section{Tree Growth, Photosynthesis, and Leaf Morphology} Trunk diameter, measured $50 \mathrm{~cm}$ aboveground, and tree height were measured at planting and in late autumn from 2003 to 2004 for both paper birch and Austrian pine, and again in late autumn 2005 for Austrian pine. Annual tree growth was calculated by subtracting consecutive measurements for diameter and height.

Light-saturated photosynthesis was quantified using a LICOR LI-6200 Portable Photosynthesis System (LI-COR, Inc., Lincoln, Nebraska, U.S.). Measurements were taken from paper birch on June 25, July 25, and August 14 in 2003, and July 21 in 2004; and from Austrian pine on August 24, 2004. Leaves sampled were standardized for exposure and age, and mea- surements were made during cloud-free mornings (9:00-11:00 am) to ensure that measurements reflected treatment effect on tree physiology rather than other environmental factors affecting stomatal aperture. The blocking design of the experiment provided additional control over environmental variation.

Leaf area and specific leaf mass were quantified for paper birch on June 24, 2003 and July 7, 2004 by sampling 12 leaves throughout the canopy. Leaf age and exposure were standardized by sampling the youngest fully mature leaves with full exposure to sunlight. Austrian pine foliage was sampled on October 24, 2004 and June 29, 2005 by collecting from throughout the canopy 12 needle fascicles that had formed in the previous year. Leaf area of 12 sampled birch leaves per tree was determined using imaging software [CI-400 Computer Image Analysis System and software (CID, Inc.)], and for each pine tree by measuring the length and diameter of one needle from each fascicle (Svenson and Davies 1992), after which leaves/needles were dried to constant weight $\left(85^{\circ} \mathrm{C}\right.$ for 72 hours). Specific leaf and needle mass $\left(\mathrm{g} / \mathrm{m}^{2}\right)$ was determined for birch and pine, respectively, by dividing sampled leaf/needle dry mass by its area.

\section{Phytochemistry}

Nitrogen concentration was quantified for paper birch foliage once in 2003 (June 24) and twice in 2004 (June 14 and August 24), and for Austrian pine previous-year needles on May 6, 2004 and May 10, 2005. Leaf and needle samples were freeze-dried at $-4^{\circ} \mathrm{C}$ using an FTS temperature-controlled tray freezedryer, and ground in a mill (Cyclotec EC 1093, Tecator AB, Hoganas, Sweden) to pass through a $0.4 \mathrm{~mm}$ mesh screen. A subsample of $7 \mathrm{mg}$ of this fine powder was used to quantify total leaf and needle nitrogen using a Carbo Erba CHN analyzer, Model NA 1500 (Daun and DeClerq 1994).

Foliar concentrations of condensed tannins and total phenolic compounds were quantified on three dates for paper birch (June 24, 2003; June 14, 2004; and August 24, 2004), and for Austrian pine with previous-year foliage sampled on May 9, 2003 and May 6, 2004, and current-year foliage sampled on August 24,2004 . Condensed tannins (proanthocyanidins) were quantified using the $\mathrm{H}_{2} \mathrm{SO}_{4}$ method, and total foliar phenolics concentrations were quantified using the Folin-Denis assay. These colorimetric methods were modified for use with an automated continuous flow analyzer as documented in detail by Nitao et al. (2001). Commercially available "ground ordinary quebracho tannin" (L.H. Lincoln \& Son, Inc., Coudersport, Pennsylvania, U.S.) was used as an internal standard. Calibration curves for the internal standard in relation to purified tannins (either from red pine or paper birch foliage) were used to quantify tannins and phenolics in the samples, with concentrations reported as tannic acid equivalents on a percent dry mass basis.

Foliar terpene concentrations of one-year-old Austrian pine needles were quantified on three dates (May 9, 2003; May 6, 2004; and May 10, 2005). Immediately upon sampling, needles were flash-frozen in the field in liquid nitrogen, placed in a cooler on ice, and then transported to the lab, where they were stored at $-80^{\circ} \mathrm{C}$ until analysis. Concentrations of monoterpenes ( $\alpha$-pinene, $\beta$-pinene, myrcene, camphene, limonene, and bornyl-acetate), and sesquiterpenes (trans-caryophyllene, alpha-humulene, and germacrene-D) were analyzed via gas chromatography (GCFID) following extraction of $1 \mathrm{~g}$ of fresh weight needles in 10 
ml n-pentane for 48 hours (Raffa and Steffeck 1988; Codella and Raffa 1995). Terpene concentrations in extracts were measured using a Shimadzu GC-17A gas chromatograph equipped with an Rtx-5 fused silica column $(15 \mathrm{~m} \times 0.25 \mathrm{~mm}$ inside diameter $\times$ $0.25 \mu \mathrm{m}$ film thickness). Nitrogen was used as a carrier gas at a linear velocity of $29.6 \mathrm{~cm} / \mathrm{sec}$. The temperature program was $60^{\circ} \mathrm{C}$ for five minutes, increased by $5^{\circ} \mathrm{C}$ per minute to $110^{\circ} \mathrm{C}$, then increased by $10^{\circ} \mathrm{C}$ per minute to $200^{\circ} \mathrm{C}$, and then by $25^{\circ} \mathrm{C}$ per minute to $250^{\circ} \mathrm{C}$, and finally held at $250^{\circ} \mathrm{C}$ for five minutes. Total analysis time was 31 minutes. The injector and detector temperatures were $220^{\circ} \mathrm{C}$ and $230^{\circ} \mathrm{C}$, respectively. Quantification was based on pure standards, except germacrene-D, which was identified based on EI spectra because no standard was available. Its concentration was estimated according to the response factor for another sesquiterpene, trans-caryophyllene. Results are presented as the sum of individual mono- and sesquiterpenes in milligrams per gram of fresh foliage weight.

\section{Tree Resistance to Insects}

Treatment effects on birch resistance to defoliating insects were measured in bioassays initiated for forest tent caterpillar on May 9, 2003, gypsy moth on May 9, 2003 and May 25, 2004, and whitemarked tussock moth on August 25, 2004. Resistance of Austrian pine to European pine sawfly was quantified in bioassays initiated on April 21, 2003; May 10, 2004; and May 11, 2005. These dates correspond to the natural feeding phenology of these insects.

Growth of larvae feeding on foliage from experimental trees was measured in laboratory bioassays that lasted for 10 days. For birch-feeding caterpillars, a group of five neonate larvae was weighed collectively and placed in a polystyrene Petri dish $(15 \times 3 \mathrm{~cm})$ containing a base of plaster mixed with activated charcoal with foliage that had just been harvested from one of the experimental plants. To control for ontogenetic variation in leaf quality, all insects received leaves of the same age (youngest fully expanded leaf). The plaster base of each dish was saturated with distilled water to maintain turgor of detached leaves over the course of the bioassay, and foliage was replaced with fresh leaves every 48 hours. Bioassays were conducted in a growth chamber at $25^{\circ} \mathrm{C}$ with a 16:8 (L:D) photoperiod. Larval survival was recorded, and living larvae were weighed as a group at the end of the 10-day bioassay, and mean final weight was calculated by dividing total weight by number of larvae. Larval growth (mg) was calculated as the difference between mean final and mean initial mass. Bioassays with European pine sawfly larvae were conducted as previously described, except that 10 larvae were confined in each petri dish and fed one-year-old needles.

\section{Data Analyses}

Effects of block, paclobutrazol, fertilization, and their interactions on tree growth and physiological measurements, leaf traits, and chemistry, as well as insect growth and survival were assessed by analysis of variance (PROC GLM, Type III sums of squares; SAS Institute, Inc. 2003). Following significant $F$-tests $(\alpha=0.05)$, the PDIFF option following the LSMEANS statement was used to make pairwise comparisons $(\alpha=0.05)$. Fertilization and paclobutrazol treatments were considered fixed factors. Initial larval weight was included as a covariate in the model when analyzing larval growth. Vapor pressure deficit was used as a covariate when analyzing photosynthesis and stoma- tal conductance. Initial measures of trunk diameter were used as covariates for analysis of tree growth measurements. All variables met assumptions of homoscedasticity and normal distribution of residuals. Data are presented as least squares means \pm one standard error. Pearson's correlation coefficients (PROC CORR SAS 9.3) were used to quantify relationships among dependent variables (e.g., between leaf chemistry and tree growth). Prior to correlation analysis, bivariate plots were inspected to ensure that none of the analyzed relationships were curvilinear.

\section{RESULTS}

\section{Tree Growth}

Paclobutrazol significantly decreased the height and radial trunk growth of paper birch in 2003 and, to a lesser extent, in 2004 (Figure 1). The growth-inhibiting response to paclobutrazol was observed in fertilized as well as non-fertilized paper birch trees (significant main effect of paclobutrazol, no significant paclobutrazol * fertilization interaction) (Table 1). Similarly, paclobutrazol substantially decreased the height and trunk diameter growth of Austrian pine in all three years (Figure 1). The growth-inhibiting response to paclobutrazol was also observed in fertilized as well as non-fertilized Austrian pine trees (no significant paclobutrazol * fertilization interaction). Fertilization had no effect on height or diameter growth of either species (Table 1).

\section{Photosynthesis}

Neither paclobutrazol, fertilization, nor their interaction had an effect on net photosynthesis rate of paper birch or Austrian pine on any date measured, with the exception of August 14, 2003, when paclobutrazol decreased photosynthesis of paper birch by $17 \%$ relative to untreated trees (Figure 2; Table 2).

\section{Leaf Morphology}

Paclobutrazol decreased the area of individual paper birch leaves in 2003 and 2004 (Table 1; Figure 3). Paper birch leaves from paclobutrazol-treated trees also exhibited noticeable curling in 2003 and were a darker shade of green. Paclobutrazol increased specific leaf mass (leaf mass per unit area) of paper birch in 2003 but had no effect in 2004 (Table 1; Figure 3).

Paclobutrazol had no effect on leaf area of one-yearold Austrian pine needles in 2004 or 2005, or specific leaf mass in 2004 (Table 1; Figure 3). However, when measured in 2005, paclobutrazol increased specific mass of previous-year needles (formed in 2004) (Table 1; Figure 3).

Fertilization decreased specific leaf mass of paper birch in $2004,70.7 \pm 2.1 \mathrm{~g} / \mathrm{m}^{2}$ versus $76.7 \pm 1.7 \mathrm{~g} / \mathrm{m}^{2}$, for fertilized and non-fertilized trees, respectively, but otherwise had no effect on birch leaf morphology (Table 1). Fertilization had no effect on needle morphology of Austrian pine (Table 1).

\section{Phytochemistry and Foliar Nitrogen}

Paclobutrazol had no effect on the nitrogen concentration of paper birch or Austrian pine, except for a slight increase in paper birch foliar nitrogen in August 2004 (Table 3). However, fertilization did increase foliar nitrogen of paper birch on June 24, 2003 (3.15 $\pm 0.11 \%$ versus $2.83 \pm 0.11 \%$, for fertilized and non-fertilized 


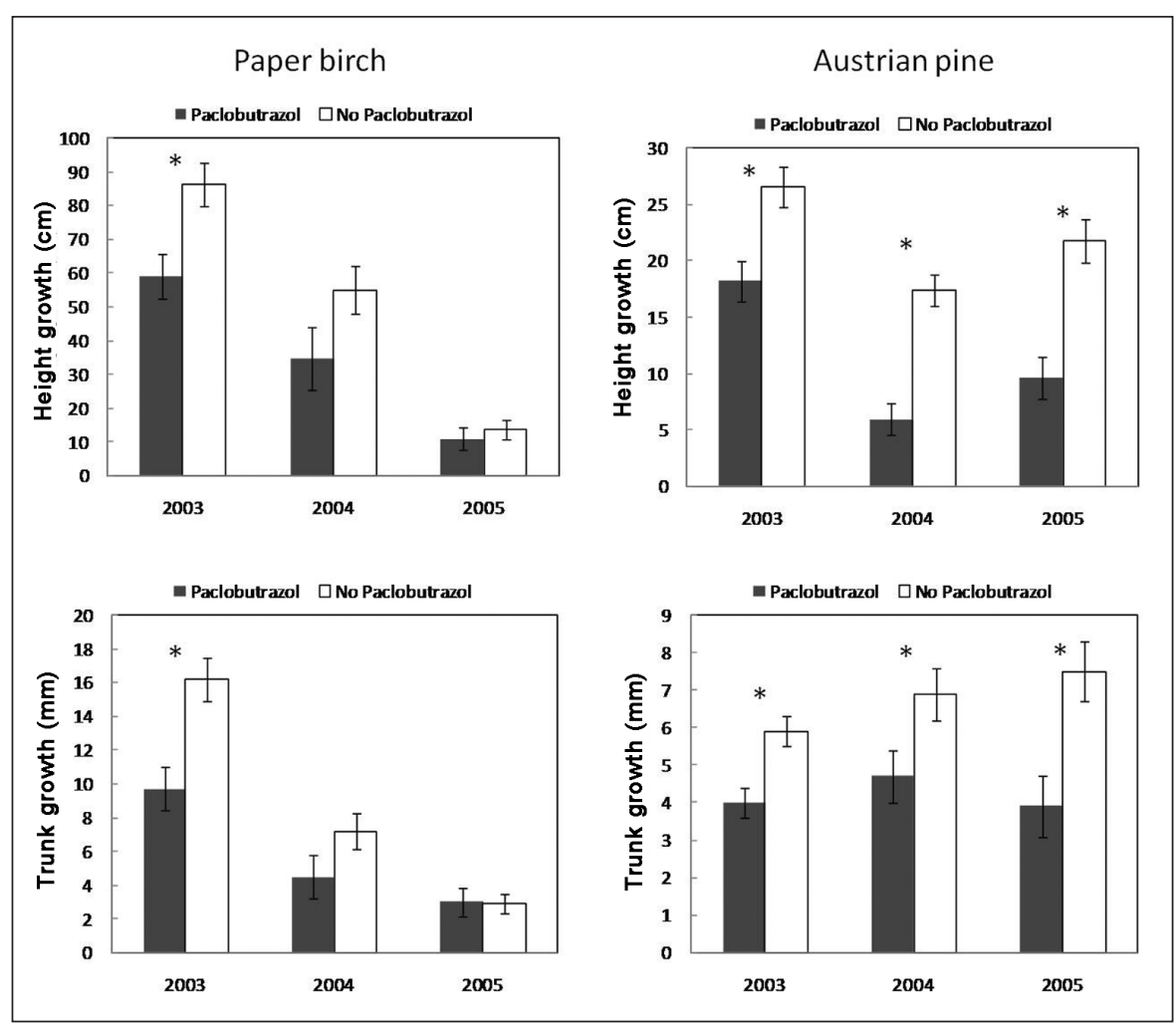

Figure 1. Effects of paclobutrazol on growth of paper birch and Austrian pine. Data are presented as least squares means $\pm 1 \mathrm{SE}$. Exact statistical significance $\left(^{*}\right)$ is reported in Table 1.

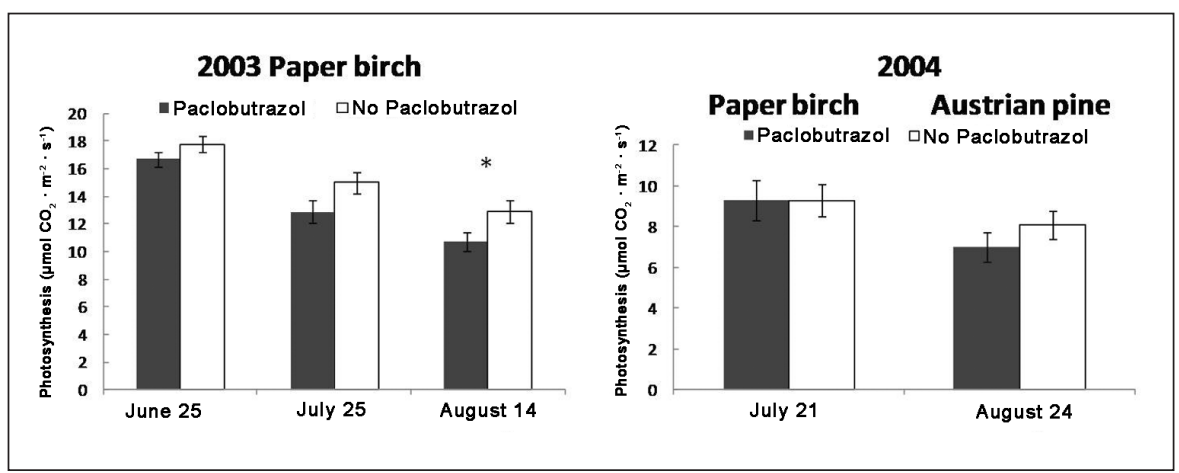

Figure 2. Effects of paclobutrazol on photosynthesis of paper birch and Austrian pine. Data are presented as least squares means $\pm 1 \mathrm{SE}$. Exact statistical significance $\left(^{*}\right)$ is reported in Table 2.

trees, respectively), and on August 24, 2004 (2.19 $\pm 0.1 \%$ versus $1.87 \pm 0.1 \%$, for fertilized and non-fertilized trees, respectively) (Table 3). Fertilization had no effect on nitrogen concentration of one-year-old foliage of Austrian pine on May 6, 2004 (1.55 \pm $0.1 \%$ versus $1.39 \pm 0.1 \%$, for fertilized and non-fertilized trees, respectively), or on May 10, 2005 (1.25 $\pm 0.1 \%$ versus $1.24 \pm 0.1 \%$, for fertilized and non-fertilized trees, respectively) (Table 3).

\section{Secondary Metabolism}

Paclobutrazol increased foliar condensed tannin concentrations of paper birch by $35 \%$ on June 24, 2003 (Table 3; $21.5 \pm 1.5 \%$ versus $15.9 \pm 1.5 \%$ for paclobutrazol-treated fertilized and non- treated trees, respectively), but otherwise had no effect on total phenolics or tannin concentrations in 2003 or 2004. Foliar concentrations of total phenolics and condensed tannins of Austrian pine were not affected by paclobutrazol (Table 3). Fertilization or the interaction between fertilization and the regulator had no effect on foliar tannin and phenolic concentrations of paper birch and Austrian pine (Table 3). Total foliar terpene concentrations of Austrian pine foliage were also not affected by paclobutrazol, fertilization, or their interaction (Table 3).

Trunk growth of paper birch was inversely correlated with foliar tannins and phenolic concentrations in 2003 and in 2004 (Figure 4); however, there was no significant correlation between trunk growth of Austrian pine and foliar concentrations of tannins, phenolics, or terpenes.

\section{Insect Performance}

In 2003, paclobutrazol did not affect resistance of paper birch to gypsy moth or forest tent caterpillar, as evidenced by no difference in larval growth (Table 4; Figure 5) or survival (data not shown). However, paclobutrazol increased resistance of paper birch to both gypsy moth and whitemarked tussock moth in 2004, as evidenced by decreased growth of larvae on treated trees (Table 4; Figure 5). However, larval survival was not affected. Paclobutrazol had no effect on growth or survival of European pine sawfly larvae on Austrian pine in either year (Table 4; Figure 5).

Fertilization had no effect on gypsy moth survival but increased larval growth by $30 \%$ in $2004(38.3 \pm 3.4 \mathrm{mg}$ versus $29.7 \pm 2.7 \mathrm{mg}$ on fertilized and non-fertilized trees, respectively). Fertilization had no effect on gypsy moth growth and survival in 2003, nor did it have any effect on the other insect species in either 2003 or 2004 (Table 4).

\section{Notable Physiological Responses}

Paclobutrazol induced premature leaf senescence (yellowing) of paper birch beginning in mid-August 2003, and abscission in early September, which occurred about one month prior to untreated trees. The effect was most prominent on older foliage in the interior of the canopy. No such response was observed in 2004 or in Austrian pine in any year. Paclobutrazol dramatically stimulated female reproductive effort of paper birch in 2004 (207.3 versus 1.8 pistillate catkins/tree for paclobutrazol-treated and untreated trees, respectively). Although paper birch is a monecious species (Perala and Alm 1990), paclobutrazol had no effect on male (staminate) cat- 


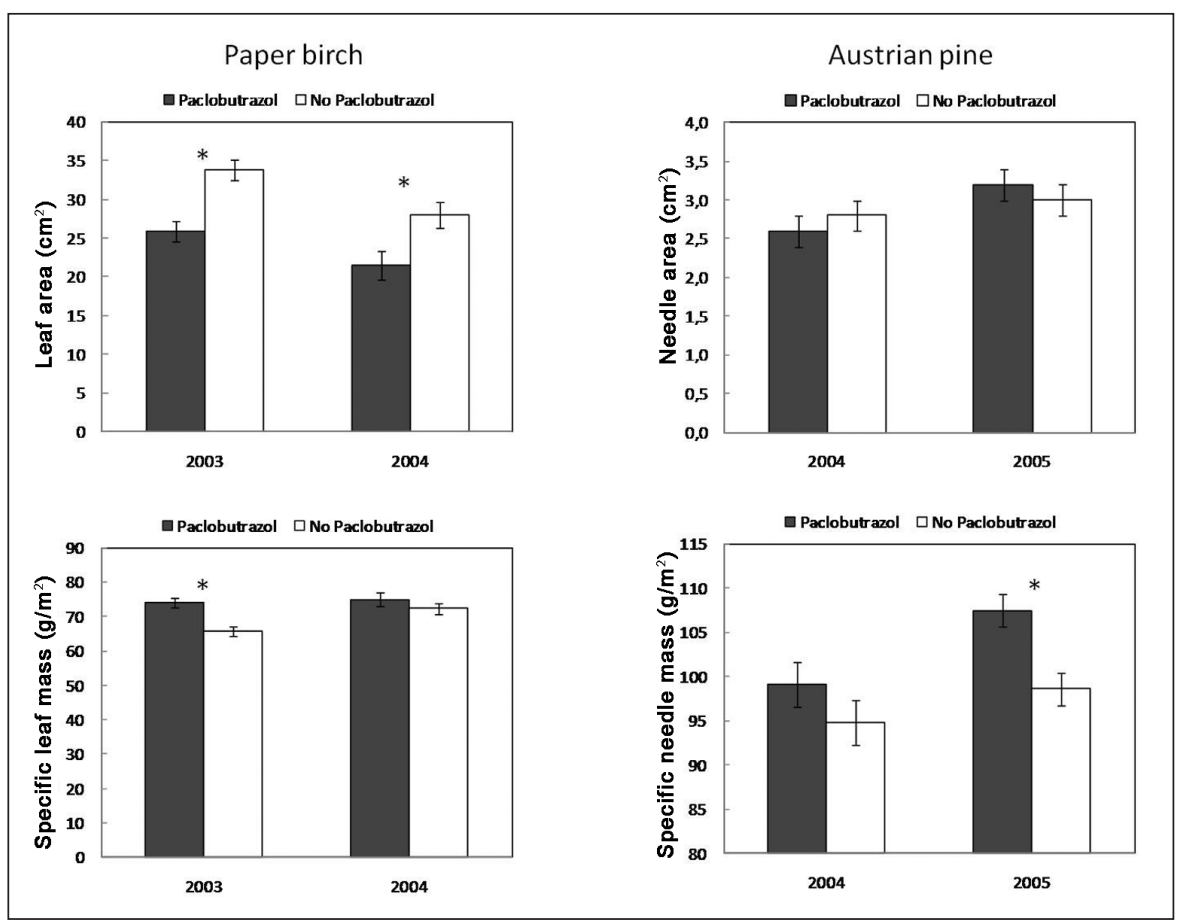

Figure 3. Effects of paclobutrazol on leaf/needle morphology of paper birch and Austrian pine. Data are presented as least squares means $\pm 1 \mathrm{SE}$. Exact statistical significance (*) is reported in Table 1. kin production. Fertilization had no effect on the reproductive efforts of paper birch.

\section{DISCUSSION}

Paclobutrazol soil drench in autumn 2002 had substantial physiological effects on paper birch and Austrian pine that extended throughout the study period (2004 and 2005, respectively). The regulator slowed the growth of both paper birch and Austrian pine with little effect on photosynthesis (although photosynthesis of paper birch was significantly lower in paclobutrazol-treated trees on one occasion in August 2003). These results accord generally with other studies that showed paclobutrazol to reduce growth (Wheeler 1987; Coffelt et al. 1993; Yim et al. 1997) with no effect on photosynthesis (Wieland and Wample 1985; Archbold and Houtz 1988; $\mathrm{Vu}$ and Yelenosky 1988; Yim et al. 1997).

Decreased growth of paper birch was associated with decreased area of individual leaves in 2003 and 2004, and increased specific leaf mass in 2003, which are morphological responses typically associated with slower growth rates (McDonald 1990;

Table 1. F and $\mathrm{P}$ values from ANOVA for growth and leaf/needle morphology of paper birch (Betula pendula) and Austrian pine (Pinus nigra), in response to paclobutrazol and fertilization applied alone or in combination.

\begin{tabular}{|c|c|c|c|c|c|c|}
\hline & \multicolumn{6}{|c|}{ Source of variation } \\
\hline & \multicolumn{2}{|c|}{ Paclobutrazol $(P)$} & \multicolumn{2}{|c|}{ Fertilization $(F)$} & \multicolumn{2}{|c|}{ Interaction $P \times F$} \\
\hline & $F$-value & $P$-value & $F$-value & $P$-value & $F$-value & $P$-value \\
\hline \multicolumn{7}{|l|}{ Paper birch } \\
\hline 2003 & 9.20 & 0.005 & 0.01 & 0.919 & 1.74 & 0.196 \\
\hline 2004 & 3.33 & 0.081 & 0.13 & 0.727 & 0.44 & 0.512 \\
\hline \multicolumn{7}{|l|}{ Trunk growth (mm) } \\
\hline 2003 & 13.11 & $<0.001$ & 0.22 & 0.643 & 0.68 & 0.417 \\
\hline 2004 & 2.96 & 0.098 & 0.42 & 0.521 & 0.26 & 0.615 \\
\hline \multicolumn{7}{|l|}{ Leaf area $\left(\mathrm{cm}^{2}\right)$} \\
\hline 2003 (June 24) & 19.19 & $<0.001$ & 0.10 & 0.758 & 0.21 & 0.647 \\
\hline 2004 (July 7) & 7.36 & 0.012 & 0.08 & 0.782 & 0.34 & 0.565 \\
\hline \multicolumn{7}{|c|}{ Specific leaf mass $\left(\mathrm{g} / \mathrm{m}^{2}\right)$} \\
\hline 2003 (June 24) & 15.92 & $<0.001$ & 0.13 & 0.716 & 0.16 & 0.688 \\
\hline 2004 (July 7) & 1.05 & 0.314 & 5.12 & 0.032 & 0.13 & 0.723 \\
\hline \multicolumn{7}{|l|}{ Austrian pine } \\
\hline 2003 & 11.45 & 0.002 & 0.78 & 0.383 & 0.61 & 0.440 \\
\hline 2004 & 31.56 & $<0.001$ & 0.52 & 0.474 & 0.32 & 0.576 \\
\hline 2005 & 19.66 & $<0.001$ & 0.84 & 0.365 & 0.01 & 0.920 \\
\hline \multicolumn{7}{|l|}{ Trunk growth (mm) } \\
\hline 2003 & 10.94 & 0.002 & 2.16 & 0.149 & 0.24 & 0.626 \\
\hline 2004 & 5.29 & 0.027 & 1.13 & 0.294 & 0.07 & 0.795 \\
\hline 2005 & 10.22 & 0.003 & 2.04 & 0.161 & 1.48 & 0.230 \\
\hline \multicolumn{7}{|l|}{ Needle area $\left(\mathrm{cm}^{2}\right)$} \\
\hline 2004 (October 24) & 0.69 & 0.410 & 0.25 & 0.623 & 0.00 & 0.959 \\
\hline 2005 (June 29) & 0.51 & 0.477 & 0.38 & 0.543 & 0.21 & 0.650 \\
\hline \multicolumn{7}{|c|}{ Specific needle mass $\left(\mathrm{g} / \mathrm{m}^{2}\right)$} \\
\hline 2004 (October 24) & 1.47 & 0.233 & 0.01 & 0.927 & 3.83 & 0.057 \\
\hline 2005 (June 29) & 12.10 & 0.001 & 0.32 & 0.573 & 1.19 & 0.282 \\
\hline
\end{tabular}


Table 2. $F$ and $P$ values from ANOVA for photosynthesis $\left(\mu \mathrm{mol} \mathrm{CO} \cdot \mathrm{m}^{-2} \cdot \mathrm{s}^{-1}\right)$ of paper birch (Betula pendula) and Austrian pine (Pinus nigra), in response to paclobutrazol and fertilization applied alone or in combination.

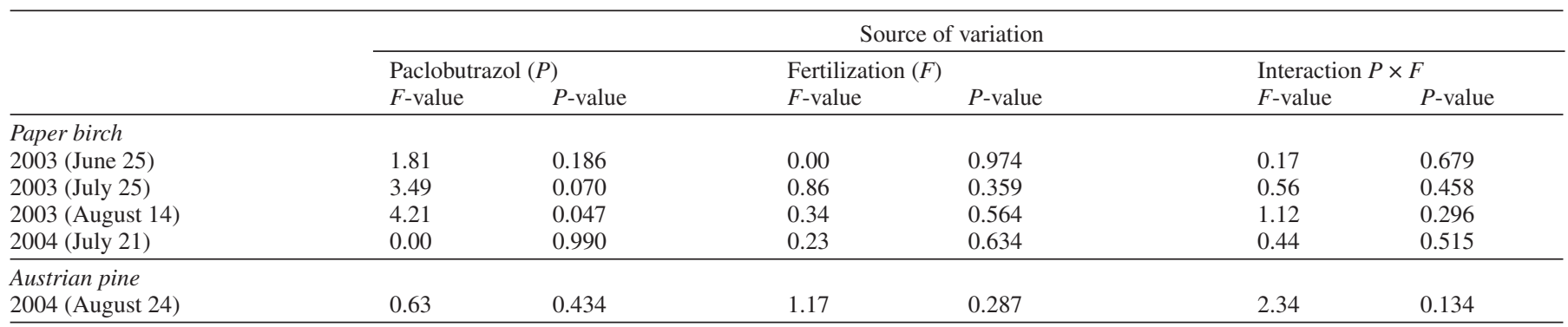

Table 3. Effects of paclobutrazol on, and $\mathrm{F}$ and $\mathrm{P}$ values from ANOVA for nitrogen and secondary metabolites of paper birch (Betula pendula) and Austrian pine (Pinus nigra) in response to paclobutrazol and fertilization applied alone or in combination.

\begin{tabular}{|c|c|c|c|c|c|c|c|c|}
\hline & \multicolumn{8}{|c|}{ Source of variation } \\
\hline & \multicolumn{2}{|c|}{ Treatment means } & \multicolumn{2}{|c|}{ Paclobutrazol $(P)$} & \multicolumn{2}{|c|}{ Fertilization $(F)$} & \multicolumn{2}{|c|}{ Interaction $P \times F$} \\
\hline & Paclobutrazol & No paclobutrazol & $F$-value & $P$-value & $F$-value & $P$-value & $F$-value & $P$-value \\
\hline \multicolumn{9}{|l|}{ Paper birch } \\
\hline \multicolumn{9}{|c|}{ Nitrogen (\% dry weight) } \\
\hline 2003 (June 24) & $3.0 \pm 0.1$ & $3.0 \pm 0.1$ & 0.04 & 0.848 & 3.94 & 0.054 & 0.16 & 0.688 \\
\hline 2004 (June 14) & $2.0 \pm 0.1$ & $2.1 \pm 0.1$ & 1.07 & 0.309 & 3.79 & 0.061 & 0.30 & 0.586 \\
\hline 2004 (August 24) & $2.1 \pm 0.1$ & $1.9 \pm 0.1$ & 5.14 & 0.032 & 12.31 & 0.002 & 0.47 & 0.501 \\
\hline \multicolumn{9}{|c|}{ Tannins (\% dry weight) } \\
\hline 2003 (June 24) & $21.5 \pm 1.5$ & $15.9 \pm 1.5$ & 6.86 & 0.012 & 0.13 & 0.716 & 0.19 & 0.661 \\
\hline 2004 (June 14) & $8.6 \pm 0.7$ & $7.4 \pm 0.6$ & 1.92 & 0.176 & 0.02 & 0.903 & 3.90 & 0.057 \\
\hline 2004 (August 24) & $10.1 \pm 1.0$ & $8.4 \pm 0.8$ & 1.97 & 0.173 & 1.17 & 0.290 & 0.25 & 0.618 \\
\hline \multicolumn{9}{|c|}{ Phenolics (\% dry weight) } \\
\hline 2003 (June 24) & $14.0 \pm 0.9$ & $12.8 \pm 0.9$ & 0.86 & 0.360 & 0.01 & 0.938 & 0.53 & 0.469 \\
\hline 2004 (June 14) & $21.8 \pm 1.0$ & $21.2 \pm 0.8$ & 0.17 & 0.679 & 0.04 & 0.835 & 0.00 & 0.969 \\
\hline 2004 (August 24) & $21.7 \pm 1.3$ & $21.4 \pm 1.2$ & 0.03 & 0.855 & 3.76 & 0.063 & 0.08 & 0.784 \\
\hline \multicolumn{9}{|c|}{ Nitrogen (\% dry weight) } \\
\hline 2004 (May 6) $^{z}$ & $1.4 \pm 0.1$ & $1.5 \pm 0.1$ & 1.23 & 0.274 & 3.10 & 0.086 & 0.15 & 0.701 \\
\hline 2005 (May 10) $^{\mathrm{z}}$ & $1.3 \pm 0.1$ & $1.2 \pm 0.1$ & 1.46 & 0.234 & 0.02 & 0.089 & 1.22 & 0.276 \\
\hline \multicolumn{9}{|c|}{ Tannins (\% dry weight) } \\
\hline $2003{\text { (May 9) }{ }^{z}}^{2}$ & $9.2 \pm 0.5$ & $8.8 \pm 0.5$ & 0.33 & 0.570 & 0.00 & 0.960 & 0.16 & 0.691 \\
\hline 2004 (May 6) $^{z}$ & $18.0 \pm 0.5$ & $17.1 \pm 0.5$ & 1.59 & 0.215 & 0.31 & 0.584 & 0.85 & 0.362 \\
\hline 2004 (August 24) $^{y}$ & $9.0 \pm 0.5$ & $8.3 \pm 0.5$ & 0.68 & 0.413 & 0.05 & 0.822 & 0.44 & 0.510 \\
\hline \multicolumn{9}{|c|}{ Phenolics (\% dry weight) } \\
\hline 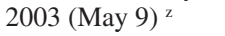 & $8.6 \pm 0.3$ & $8.1 \pm 0.3$ & 1.24 & 0.277 & 1.88 & 0.184 & 0.29 & 0.595 \\
\hline 2004 (May 6) $^{z}$ & $10.0 \pm 0.3$ & $9.3 \pm 0.3$ & 2.87 & 0.098 & 1.37 & 0.248 & 0.05 & 0.832 \\
\hline 2004 (August 24) $^{\mathrm{y}}$ & $4.4 \pm 0.3$ & $4.2 \pm 0.3$ & 0.21 & 0.646 & 0.12 & 0.730 & 0.02 & 0.895 \\
\hline \multicolumn{9}{|c|}{ Terpenes (mg/g fresh weight) } \\
\hline 2003 (May 9) $^{z}$ & $2.3 \pm 0.1$ & $2.3 \pm 0.1$ & 0.08 & 0.782 & 0.11 & 0.743 & 0.52 & 0.474 \\
\hline 2004 (May 6) $^{z}$ & $2.6 \pm 0.2$ & $3.1 \pm 0.2$ & 3.76 & 0.060 & 3.40 & 0.072 & 0.00 & 0.986 \\
\hline $2005{\text { (May } 10)^{z}}^{z}$ & $4.2 \pm 0.4$ & $5.3 \pm 0.4$ & 3.70 & 0.061 & 1.19 & 0.282 & 1.20 & 0.279 \\
\hline
\end{tabular}

${ }^{\mathrm{z}}$ previous-year foliage

y current-year foliage

Lambers and Poorter 1992). Paclobutrazol decreased growth of Austrian pine with less dramatic effects on leaf morphology, as needle area was not affected and specific leaf mass expressed a delayed response, not increasing until 2005 in one-year-old needles. Variable effects of paclobutrazol on leaf morphology have been reported in other species, as well. For example, paclobutrazol had no effect on specific leaf mass of strawberry plants four months after application (Archbold and Houtz 1988), but it increased specific leaf mass of apple trees after a similar time period (Wieland and Wample 1985). Paclobutrazol also had delayed response on leaf morphology of willow oak (Quercus phellos) (Coffelt et al. 1993).

Paclobutrazol induced premature leaf abscission of paper birch in 2003, and extremely high levels of fruit production in 2004, which may have contributed to its growthregulating effect. Heavy catkin production in paper birch has been associated with stress, and it is known to decrease vegetative growth due to internal competition for 


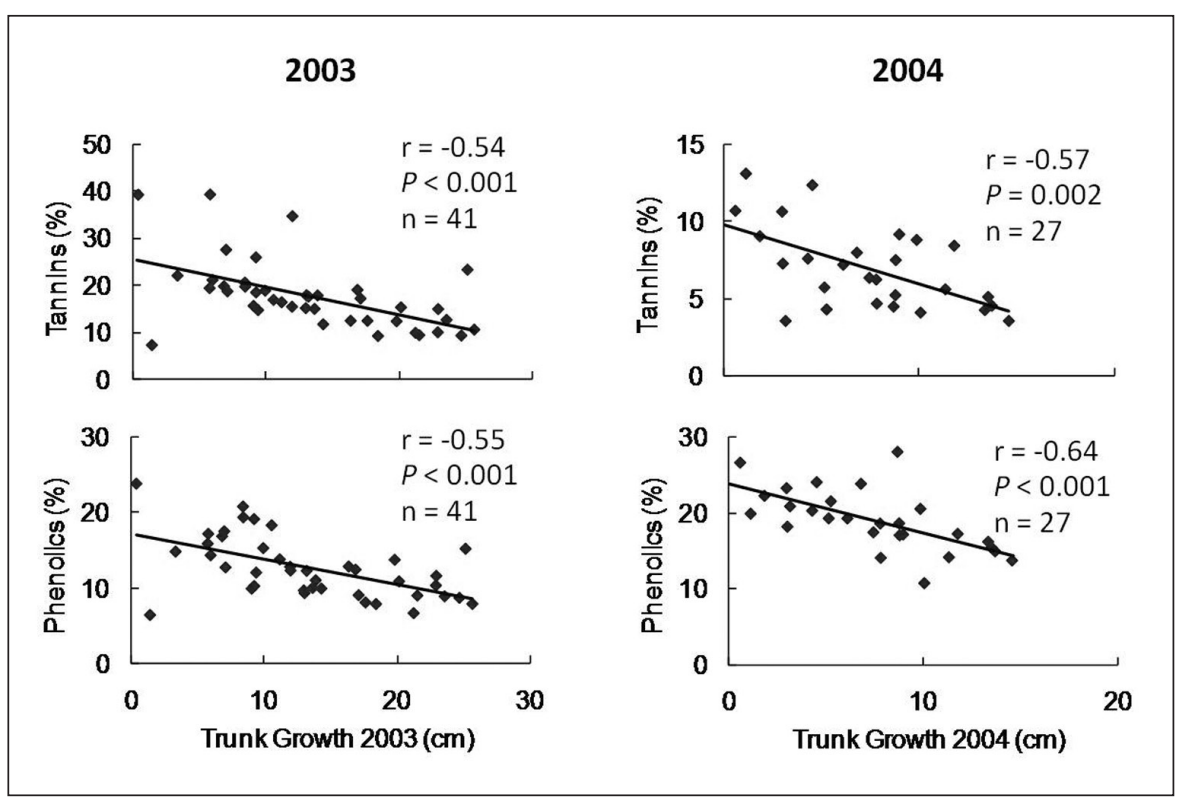

Figure 4. Linear correlation analyses between leaf chemical composition and annual diameter trunk growth of paper birch. Results for 2003 show a correlation between secondary chemicals of leaves sampled on June 24, 2003, and trunk growth during 2003. Results for 2004 show a correlation between secondary chemicals of leaves sampled on June 14, 2004, and trunk growth during 2004.

resources (Gross 1972; Tuomi et al. 1982). Other studies have also observed paclobutrazol to increase fruit production in woody plants (e.g., Struve et al. 1989; Huang et al. 1995).

The Growth/Differentiation Balance Hypothesis predicts that when growth decreases proportionally more than photosynthesis, the availability of carbon to support other processes, such as the production of secondary metabolites, will increase, thereby increasing insect resistance (Herms and Mattson 1992; Herms and Mattson 1997; Herms 2002). The responses observed in this study were only partially consistent with these predictions. As predicted, paclobutrazol increased foliar concentrations of condensed tannins, but not total phenolics, of paper birch in 2003 (in the growing season after the treatment was applied the previous autumn). However, the treatment persisted for only one year, with no effect observed in 2004. The negative correlation between growth and secondary metabolites observed in paper birch across all treatments in 2003 and 2004 is also consistent with growth-defense allocation tradeoff predicted by the Growth/Differentiation Balance Hypothesis (Herms and Mattson 1992; Herms and Mattson 1997). In one of the few studies to examine effects on secondary metabolism, Wang and Steffens (1987) also observed paclobutrazol to increase foliar phenolics in apple trees. Several studies with deciduous trees have observed paclobutrazol to increase the accumulation of storage compounds (Steffens et al. 1985; Wieland and Wample 1985; Wang et al. 1986; Yim et al. 1997), which is often associated with increased biosynthesis of secondary metabolites (Herms 2002).

Effect of paclobutrazol on insect growth did not correspond closely with effects on secondary chemistry. It had no effect on larval growth of gypsy moth and forest tent caterpillar in 2003, the year that paclobutrazol increased foliar concentrations of condensed tannins. However, paclobutrazol did increase paper birch resistance to gypsy moth and white-marked tussock moth in 2004, which is con- sistent with a well-documented pattern that slower growing trees are more resistant to defoliating insects (Herms 2002).

Given that paclobutrazol substantially decreased growth of Austrian pine with no effect of photosynthesis, the lack of any effect on condensed tannins, total phenolics, and terpenes, as well as the lack of negative correlations between tree growth and secondary metabolism, are inconsistent with the prediction of allocation theory of a physiological tradeoff between growth and defense in Austrian pine (Herms and Mattson 1992). Paclobutrazol also had no effect on growth of European pine sawfly larvae, but this is not surprising given the lack of effect on foliar concentrations of nitrogen or secondary metabolites. Hartman et al. (2009) also found that the regulator decreased growth of Austrian pine, but with no effect on resistance to diplodia tip blight pathogen, Diplodia pinea.

Other studies also have observed variable effects of paclobutrazol on plant resistance to insects and mites. For example, the regulator decreased populations of twospotted spider mite (Tetranychus urticae) on ageratum (Ageratum houstonianum) after four weeks, while populations of thrips (Frankliniella occidentalis) and green peach aphid (Myzus persicae) were not affected (Latimer and Oetting 1999). In the same study, paclobutrazol had no effect on pest resistance of other herbaceous species including columbine (Aquilegia $\times$ hybrida), New Guinea impatiens (Impatients hawkeri), and marigold (Tagetes erecta). Drench application of paclobutrazol reduced the number of pear rust mites (Epitrimerus pyri) on pear (Raese and Burts 1983), while foliar sprays reduced the population level of pear rust mite and pear psyllid (Cacopsylla pyricola) (Campbell et al. 1989). Interestingly, the foliar spray applications had no direct contact insecticidal activity, suggesting that effects on pests were mediated by physiological responses of the host plant to paclobutrazol. Recommended rates of paclobutrazol applied as a soil drench did not consistently affect the survival or developmental time of orangestriped oakworm (Anisota senatoria) on willow oak, although higher rates $(4 \times$ recommended) did increase tree resistance to this insect (Coffelt et al. 1993).

In this study, fertilization had no effect on growth of paper birch or Austrian pine, which suggests that the native soils were inherently fertile enough to fully meet the nutrient requirements of both species. This pattern has also been observed frequently in other fertilization experiments with trees (reviewed in Struve 2002). Fertilization also had no effect on secondary metabolism of paper birch or Austrian pine, which is consistent with the Growth/Differentiation Balance Hypothesis, given that fertilization also had no effect on tree growth (Herms 2002). The increased growth of gypsy moth on fertilized birch trees in 2004 is consistent with numerous studies that have found fertilization to decrease insect resistance of trees (Herms 2002). Contrary to conventional wisdom (e.g., Smith 1978; Iles 2000; Smiley 2007), researchers in this study 
observed no evidence that fertilization increased insect resistance of trees. Indeed, the authors are not aware of any properly controlled studies that have found fertilization to increase insect resistance of trees (Herms 2002; Raupp et al. 2010).

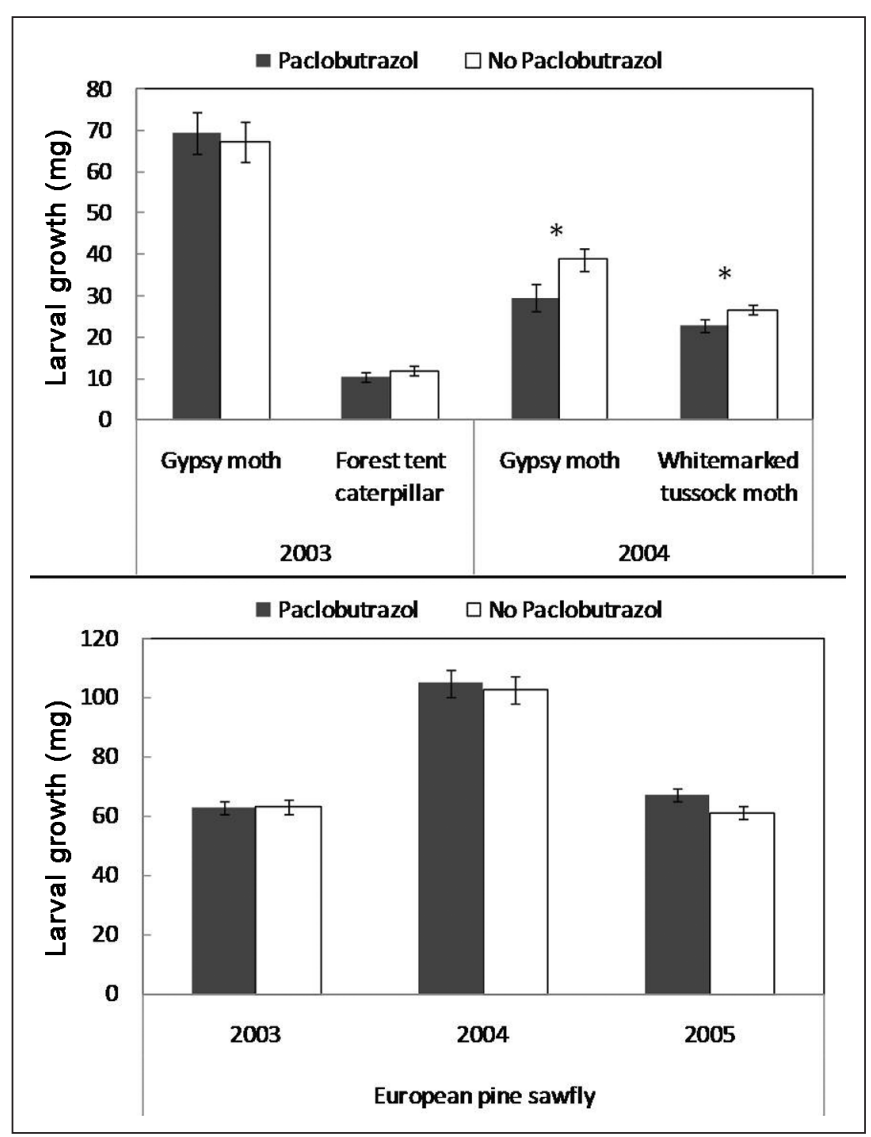

Figure 5. Effects of paclobutrazol on larval growth $(\mathrm{mg})$ of gypsy moth, white-marked tussock moth and forest tent caterpillar on paper birch, and European pine sawfly larvae on Austrian pine. Data are presented as least squares means $\pm 1 \mathrm{SE}$. Exact statistical significance $(*)$ is reported in Table 4.

\section{CONCLUSION}

Recommended rates of paclobutrazol had powerful growthregulating effects on paper birch and Austrian pine. Associated physiological effects on paper birch included decreased leaf area, increased specific leaf mass, and dramatically increased production of female catkins. However, decreased growth of Austrian pine was not associated with such substantial effects on leaf morphology. Effects of paclobutrazol on secondary metabolism and insect resistance were speciesspecific and time-sensitive. For example, in the year after treatment, paclobutrazol increased concentrations of condensed tannins, which can contribute to increased herbivore resistance (Bernays et al. 1989) and drought stress tolerance (Bussotti et al. 1998). However, paclobutrazol did not increase insect resistance of paper birch until two years after treatment, at which time effects on secondary metabolism were no longer apparent. Conversely, paclobutrazol had no effect on secondary metabolism or insect resistance of Austrian pine.

Paclobutrazol can change the resource-allocation pattern to favor fruit and root production (Huang et al. 1995). In this study, paclobutrazol resulted in premature leaf abscission of paper birch in 2003, and extremely high levels of fruit production in 2004. Heavy catkin production in paper birch has been associated with stress, and it is known to decrease vegetative growth due to internal competition for resources (Gross 1972). Hence, this may be considered an undesirable effect, especially in juvenile trees.

Acknowledgments. We thank Bryant Chambers, Diane Hartzler, Alejandro Chiriboga, and Matt Solensky for technical assistance with this study. This research was funded by grants from the John Z. Duling Program of the Tree Research and Education Endowment Fund, Rainbow Treecare Scientific Advancements, the Ohio Agricultural Research and Development Center SEEDS Matching Grant Competition, and by State and Federal funds appropriated to the Ohio Agricultural Research and Development Center and The Ohio State University.

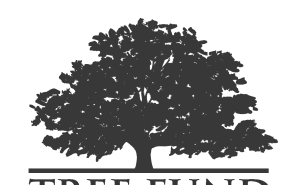

Table 4. $\mathrm{F}$ and $\mathrm{P}$ values from ANOVA for larval growth fed paper birch (Betula pendula) leaves or Austrian pine (Pinus nigra) needles collected from experimental trees.

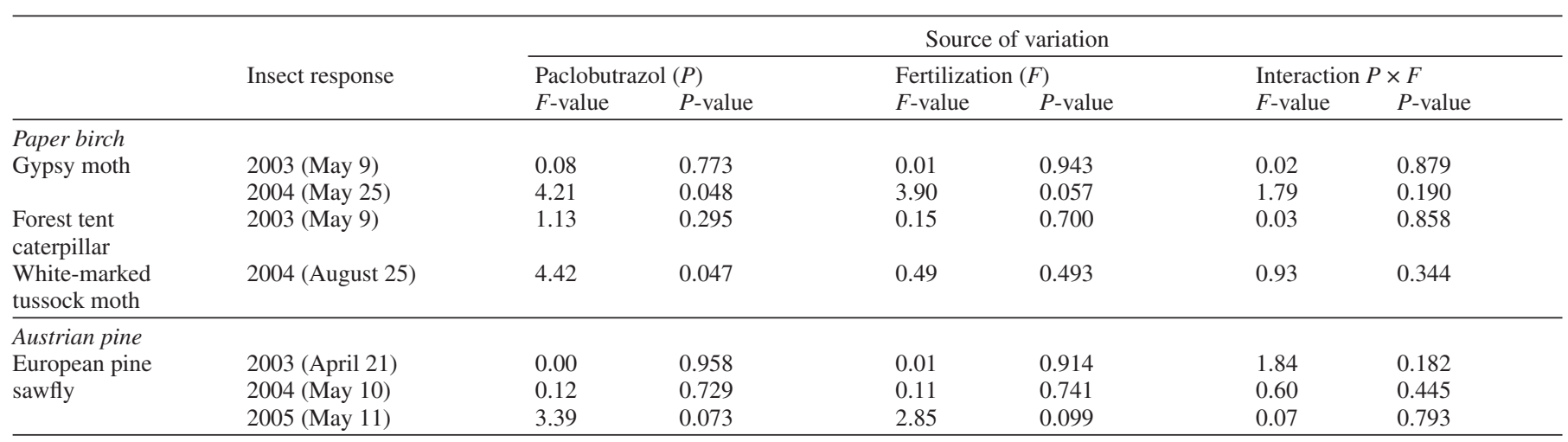




\section{LITERATURE CITED}

ANSI. 2004. American National Standard for Tree Care Operations Tree, Shrub, and Other Woody Plant Maintenance - Standard Practices (Fertilization). ANSI A300 (Part 2) - 2004 Fertilization revision of ANSI A300 (Part 2) - 1998

Archbold, D.D., and R.L. Houtz. 1988. Photosynthetic characteristics of strawberry plants treated with paclobutrazol or flurprimidol. HortScience 23:200-202.

Bai, S., W. Chaney, and Y. Qi. 2004. Response of cambial and shoot growth in trees treated with paclobutrazol. Journal of Arboriculture 30:137-143.

Bernays, E.A., G. Cooper Driver, and M. Bilgener. 1989. Herbivores and plant tannins. Advances in Ecological Research 19:263-302.

Blaedow, R.A., W.R. Chaney, P.C. Pecknolds, and H.A. Holt. 2006. Investigation of fungicidal properties of the tree growth regulator paclobutrazol to control apple scab. Arboriculture \& Urban Forestry 32:67-73.

Bussotti, F., E. Gravano, P. Grossoni, and C. Tani. 1998. Occurrence of tannins in leaves of beech trees (Fagus sylvatica) along an ecological gradient, detected by histochemical and ultrastructural analyses. New Phytologist 138:469-479.

Campbell, C.A.M., M.A. Easterbrook, and A.J. Fisher. 1989. Effect of the plant growth regulators paclobutrazol and chlormequat chloride on pear psyllid (Cacopsylla pyricola (Foerster)) and pear rust mite (Epitrimerus piri (Nal.)). Journal of Horticultural Science 64:561-564.

Codella, S.G., and K.F. Raffa. 1995. Host plant influence on chemical defense in conifer sawflies (Hymenoptera: Diprionidae). Oecologia 104:1-11.

Coffelt, M.A., P.B. Schultz, and T.J. Banko. 1993. Tree growth regulator influences orangestriped oakworm (Lepidoptera: Saturniidae) development and survival. Journal of Economic Entomology $86: 1446-1452$.

Collins, C., and B. Rawnsley. 2008. Effect of gibberellic acid and paclobutrazol on the incidence of primary bud necrosis in cv. shiraz (Vitis vinifera L.). American Journal of Enology and Viticulture 59:83-87.

Daun, J.K., and D.R. DeClerq. 1994. Comparison of combustion and Kjeldahl methods for determination of nitrogen in oilseeds. Journal of Chemical Ecology 25:1427-1440.

DeStefano, D.A., A.P. Grybauskas, J.L. Sherald, B. Momen, Q. Huang, and J.H. Sullivan. 2007. Effect of the growth regulator paclobutrazol on growth of the bacterial pathogen Xylella fastidiosa. Arboriculture \& Urban Forestry 33:246-252.

Glynn, C., D.A. Herms, C.M. Orians, R.C. Hansen, and S. Larsson. 2007. Testing the growth-differentiation balance hypothesis: Dynamic responses of willows to nutrient availability. New Phytologist 176:623-634.

Gross, H.L. 1972. Crown deterioration and reduced growth associated with excessive seed production by birch. Canadian Journal of Botany 50:2431-2437.

Hartman, J.R., L.J. Vaillancourt, J.L. Flowers, and A.M. Bateman. 2009. Managing diplodia tip blight of landscape Austrian pines. Arboriculture \& Urban Forestry 35:27-32.

Herms, D.A. 2002. Effects of fertilization on insect resistance of woody ornamental plants: Reassessing an entrenched paradigm. Environmental Entomology 31:923-933.

Herms, D.A., and W.J. Mattson. 1992. The dilemma of plants: To grow or defend. Quarterly Review of Biology 67:283-335.

Herms, D.A., and W.J. Mattson. 1997. Trees, stress, and pests. pp. 13-25. In: J.E. Lloyd (ed.). Plant Health Care for Woody Ornamentals. International Society of Arboriculture, Savoy, Illinois, U.S.
Huang, W.D., T. Shen, Z.H. Han, and S. Liu. 1995. Influence of paclobutrazol on photosynthesis rate and dry matter partitioning in the apple tree. Journal of Plant Nutrition 18:901-910.

Iles, J. 2000. Fertilizing landscape trees and shrubs. Arbor Age 20(12):17-22

Lambers, H., and H. Poorter. 1992. Inherent variation in growth rate between higher plants: a search for physiological causes and ecological consequences. Advances in Ecological Research 23:187-261.

Latimer, J.G., and R.D. Oetting. 1999. Conditioning treatments affect insect and mite populations on bedding plants in the greenhouse. HortScience 34:235-238.

Mann, M.P., H.A. Holt, W.R. Chaney, W.L. Mills, and R.L. McKenzie. 1995. Tree growth regulators reduce line clearance trimming time. Journal of Arboriculture 21:209-212.

Marshall, J.G., R.G. Rutledge, E. Blumwald, and E.B. Dumbroff. 2000. Reduction in turgid water volume in jack pine, white spruce and black spruce in response to drought and paclobutrazol. Tree Physiology 20:701-707.

McDonald, A.J.S. 1990. Phenotypic variation in growth rate as affected by N-supply: its effects on net assimilation rate (NAR), leaf weight ratio (LWR) and specific leaf area (SLA), pp. 35-44. In: H. Lambers, M.L. Cambridge, H. Konings, and T.L. Pons (eds.). Causes and Consequences of Variation in Growth Rate and Productivity of Higher Plants. SPB Publishing, The Hague, Netherlands.

Nitao, J.K., B.A. Birr, M.G. Nair, D.A. Herms, and W.J. Mattson. 2001. Rapid quantification of proanthocyanidins (condensed tannins) with a continuous flow analyzer. Journal of Agricultural and Food Chemistry 49:2207-2214.

Perala, D.A., and A.A. Alm. 1990. Reproductive ecology of birch: a review. Forest Ecology and Management 32:1-38.

Percival, G.C., and A.M.S. AlBalushi. 2007. Paclobutrazol-induced drought tolerance in containerized English and evergreen oak. Arboriculture \& Urban Forestry 33:397-409.

Rademacher, W. 2000. Growth retardants: Effects on gibberellin biosynthesis and other metabolic pathways. Annual Review of Plant Physiology and Plant Molecular Biology 51:501-31.

Raese, J.T., and E.C. Burts. 1983. Increased yield and suppression of shoot growth and mite populations of d'Anjou pear trees with nitrogen and paclobutrazol. HortScience 18:212-214.

Raffa, K.F., and R.J. Steffeck. 1988. Computation of response factors for quantitative analysis of monoterpenes by gas-liquid chromatography. Journal of Chemical Ecology 14:1385-1389.

Raupp, M.J., P.M. Shrewsbury, and D.A. Herms. 2010. Ecology of herbivorous arthropods in urban landscapes. Annual Review of Entomology 55:19-38.

SAS Institute. 2003. SAS for personal computer, version 9.1. SAS, Carey, North Carolina, U.S.

Smiley, E.T. 2007. Fertilization $R_{x}$. American Nurseryman 205(7):38-40.

Smith, E.M. 1978. Fertilizing trees and shrubs in the landscape. Journal of Arboriculture 4:157-161.

Steffens, G.L., S.Y. Wang, M. Faust, and J.K. Byun. 1985. Growth, carbohydrate, and mineral element status of shoot and spur leaves and fruit of 'spartan' apple trees treated with paclobutrazol. Journal of the American Society for Horticultural Science 110:850-855.

Struve, D.K. 2002. A review of shade tree nitrogen fertilization research in the United States. Journal of Arboriculture 28:252-263.

Struve, D.K., D.D. Miller, and D.C. Ferree. 1989. Chemical growth retardants increase seed yield in apple trees. Journal of Environmental Horticulture 7:75-79. 
Svenson, S.E., and F.T. Davies. 1992. Comparison of methods for estimating surface-area of water- stressed and fully hydrated pine needle segments for gas-exchange analysis. Tree Physiology 10:417-421.

Tuomi, J., P. Niemela, and R. Mannila. 1982. Resource allocation on dwarf shoots of birch (Betula pendula): Reproduction and leaf growth. New Phytologist 91:483-487.

Vu, J.C.V., and G. Yelenosky. 1988. Biomass and photosynthesis responses of rough lemon (Citrus jambhiri Lush.) to growth regulators. Canadian Journal of Plant Science 68:261-266.

Wang, S.Y., and G.L. Steffens. 1987. Effect of paclobutrazol on accumulation of organic acids and total phenols in apple wood. Journal of Plant Growth Regulation 6:209-213.

Wang, S.Y., G.L. Steffens, and M. Faust. 1986. Effect of paclobutrazol on carbohydrates in apple wood. HortScience 21:1419-1421.

Wheeler, N.C. 1987. Effect of paclobutrazol on Douglas fir and loblolly pine. Journal of Horticultural Science 62:101-106.

Wieland, W.F., and R.L. Wample. 1985. Effects of paclobutrazol on growth, photosynthesis and carbohydrate content of 'Delicious' apples. Scientia Horticulturae 26:139-147.

Yim, K.O., Y.W. Kwon, and D.E. Bayer. 1997. Growth responses and allocation of assimilates of rice seedlings by paclobutrazol and gibberellin treatment. Journal of Plant Growth Regulation 16:35-41.

\section{Rodrigo A. Chorbadjian (corresponding author) \\ Assistant Professor \\ Departamento de Ciencias Vegetales \\ Facultad de Agronomia e Ing. Forestal \\ Pontificia Universidad Catolica de Chile \\ Vicuna Mackenna 4860, Santiago, Chile \\ rchorba@uc.cl}

Daniel A. Herms

Professor

Department of Entomology

The Ohio State University

Ohio Agricultural Research and Development Center

1680 Madison Ave, Wooster 44691, OH, U.S.

\section{Pierluigi Bonello}

Professor

Department of Plant Pathology

The Ohio State University

201 Kottman Hall

2021 Coffey Road

Columbus 43210, OH, U.S.
Résumé. L'hypothèse de la balance croissance/différenciation permet de prédire que les facteurs environnementaux qui limitent la croissance des plantes plus que leur taux de photosynthèse devraient résulter en un accroissement du métabolisme secondaire ainsi que de la résistance aux insectes. L'application par mouillage du sol avec le paclobutrazol, un régulateur de croissance, a permis de ralentir la croissance du bouleau à papier (Betula papyrifera) et du pin noir d'Autriche (Pinus nigra) avec aucun effet sur la photosynthèse. En retour, les concentrations foliaires en tanins condensés (mais pas l'ensemble des composés phénoliques) se sont accrues comme prévu chez le bouleau, et ce avec un accroissement de la résistance de cette espèce face à la spongieuse (Lymantria dispar) et la chenille à houppes blanches (Orgyia leucostigma), mais seulement durant la seconde saison après le traitement. Au cours des deux années, il y avait une corrélation négative entre les concentrations foliaires en composés phénoliques totaux et en tanins condensés par rapport à la croissance chez le bouleau à papier, ce qui était conforme avec la prédiction entre croissance et défense. Inversement, chez le pin noir d'Autriche, le paclobutrazol et la fertilisation n'avaient aucun effet sur la concentration foliaire en tanins, en composés phénoliques et en terpènes, pas plus que les traitements n'avaient d'effet sur la résistance au diprion du pin sylvestre (Neodiprion sertifer). De là, les effets du paclobutrazol sur la croissance de l'arbre, le processus de défense chimique et la résistance aux insectes sont spécifiques à chaque espèce et selon la période.

Zusammenfassung. Die Hypothese zur Wachstum/Differenzierungs-Balance nimmt an, daß Umweltfaktoren, welche das Wachstum der Pflanzen mehr begrenzen als ihre Photosyntheserate, die zweitrangigen Metabolismen unterstützen und Widerstand gegen Insekten vergrößern sollen. Eine Bodenapplikation des Pflanzenwachstumsregulators Paclobutrazol verminderte das Wachstum von Papierbirken und Schwarzkiefern mit keinem Effekt auf deren Photosynthese. In Korrespondens dazu stieg, wie vorhergesagt, die Blattkonzentration von Tanninen (aber nicht der totale Phenol-Anteil) bei den Birken, welches zu einer steigenden Resistenz der Birke gegenüber

Schwammspinner und weißmarkierte Büschelmotte führte, aber nur während der zweiten Saison nach der Behandlung. In. beiden Jahren gab es eine negative Korrelation zwischen der Blattkonzentration der Gesamt-Phenole und der Tannine und dem Wachstum der Papierbirken. Es bestand Konsistenz mit den vorhergesagten Auswirkungen zwischen Wachstum und Resistenz. Im Gegensatz dazu hatten Paclobutrazol und Düngung keine Auswirkungen auf den Tannin-Gehalt, Phenole und Terpene der Blätter bei der Schwarzkiefer, noch zeigten sich bei den Behandlungen irgendwelche Auswikungen auf die Resistenz gegenüber der europäischen Rotgelbe Kiefernbuschhornblattwespe (Neodiprion sertifer). Daher sind die Effekte von Paclobutrazol auf das Baumwachstum, die chemische Widerstandsfähigkeit und Insektenresistenz artenspezifisch und zeit-sensitiv.

Resumen. La hipótesis del balance Crecimiento/Diferenciación predice que los factores ambientales limitan el crecimiento de las plantas más que su tasa de fotosíntesis y debería incrementar el metabolismo secundario y la resistencia a los insectos. La aplicación al suelo del regulador de crecimiento paclobutrazol disminuyó el crecimiento de betula (Betula papyrifera) y pino australiano (Pinus nigra) sin efecto en la fotosíntesis. En respuesta, las concentraciones foliares de taninos condensados (pero no fenoles totales) en betula incrementó como se predijo, con incremento de la resistencia de betula a la mariposa gitana (Lymantria dispar) y polilla blanca (Orgyia leucostigma), pero solamente durante la segunda estación después del tratamiento. En los dos años, hubo una correlación negativa entre concentraciones foliares de fenoles y taninos condensados y crecimiento de betula, lo cual es consistente con la predicción entre crecimiento y defensa. Inversamente, en pino australiano, paclobutrazol y fertilización no tuvieron un efecto en concentraciones foliares de taninos, fenoles y terpenos, ni los tratamientos tienen cualquier efecto sobre la resistencia a la mosca del pino europeo (Neodiprion sertifer). Por tanto, los efectos de paclobutrazol en el crecimiento del árbol, química de defensa y resistencia a los insectos fueron específicos para las especies y sensibles en el tiempo. 